\title{
PERAN DUKUNGAN KELUARGA DAN KEHARMONISAN PERKAWINAN \\ ORANG TUA DALAM PENDIDIKAN SPIRITUAL ANAK
}

\author{
Netty Herawati ${ }^{1}$, Setyaningsih ${ }^{2}$, S.Mulyanto Herlambang ${ }^{3}$ \\ 1, 2 Program studi Psikologi \\ Jurusan ilmu sosial dan ilmu budaya \\ Fakultas ilmu sosial dan ilmu budaya \\ Universitas Trunojoyo Madura \\ ${ }^{3}$ Program studi Elektro Pelayaran \\ Politeknik Pelayaran Surabaya \\ 1'herawati.netty9@gmail.com; \\ ${ }^{2}$ setyaningsih.niningg@gmail.com; \\ ${ }^{3}$ suksesbareng09@yahoo.com
}

\begin{abstract}
Abstrak
Tujuan penelitian ini untuk mengetahui peran dukungan keluarga dan keharmonisan perkawinan orang tua dalam pendidikan spiritual anak. Metode pendekatan kuantitatif dengan menggunakan tiga skala yaitu skala dukungan keluarga, skala keharmonisan perkawinan orang tua dan skala pendidikan spiritual anak. Teknik pengambilan sampel menggunakan quota sampling dengan 30 orang sampel. Teknik analisis data mengunakan analisis regresi berganda. Hasil penelitian menunjukkan bahwa ada pengaruh dukungan keluarga dan keharmonisam perkawinan orang tua terhadap pendidikan spiritual anak, dengan $\mathrm{F}$ hitung sebesar 9,696 dan signifikansi $0,001(<0,05)$. Artinya semakin besar dukungan keluarga dan semakin harmonis perkawinan orang tua maka semakin baik pendidikan spiritual anak. Besarnya kontribusi atau sumbangan efektif menunjukkan nilai $\mathrm{R}$ square sebesar 0,418 , yang artinya sumbangan efektif dukungan keluarga dan keharmonisan perkawinan orang tua terhadap pendidikan spiritual anak sebesar $41,8 \%$. Sedangkan sisanya 58,2 \% dijelaskan oleh faktor lain yang tidak diukur dalam penelitian ini.
\end{abstract}

Kata kunci : pendidikan spiritual, keharmonisan perkawinan, dukungan keluarga 


\section{Pendahuluan}

Keluarga adalah tempat di mana individu dikondisikan dan dipersiapkan untuk dapat melakukan peran di masyarakat. Oleh karena itu, orangtua harus melakukan persiapan, pelestarian, pengarahan, dan bertanggung jawab atas pendidikan dan perkembangan rohani, fisik dan psikologis anak. Dalam mendidik anak-anak secara informal, orang tua harus memainkan peran dalam menciptakan harmoni keluarga, dan mendidik anak mengenal Tuhan atau disebut juga pendidikan spiritual.

Pendidikan anak dalam spiritualitas merupakan salah satu tugas orang tua. Spiritualitas didefinisikan sebagai hubungan personal dengan alam, kehadiran universal atau kekuatan yang lebih tinggi. Namun tidak semua anak mendapatkannya sesuai yang seharusnya. Meningkatnya angka perceraian dari tahun ke tahun menunjukkan bahwa tidak terciptanya keharmonisan dalam perkawinan, sehingga tidak mampu memberikan dukungan terhadap pemenuhan kebutuhan anak, terutama kebutuhan rohani dan kebutuhan psikologis anak. Data perceraian tahun 2016 menunjukkan peningkatan 19.9\% dari 1,8 juta peristiwa dan $18.8 \%$ dari 1,9 juta peristiwa di tahun 2017 (Saifudin, 2018). Diperlukan dukungan keluarga dan keharmonisan perkawinan orang tua dalam pendidikan spiritual anak. Sari dan Jannah (2018) mengemukakan bahwa dukungan keluarga mempengaruhi pemenuhan kebutuhan spiritual. Dukungan keluarga adalah sikap, tindakan dan penerimaan keluarga terhadap anggotanya. Anggota keluarga memandang bahwa orang yang bersifat mendukung selalu siap memberikan pertolongan dan bantuan jika diperlukan (Friedman, 1998) dukungan. Dukungan keluarga merupakan unsur terpenting dalam membantu individu menghadapi kehidupan, baik dalam interaksinya kepada sesama maupun kepada yang membutuhkan pertolongan. Dukungan keluarga adalah suatu proses hubungan antara keluarga dengan lingkungan sosialnya yang dapat diakses oleh keluarga yang dapat bersifat mendukung dan memberikan pertolongan kepada anggota keluarga (Friedman, 2010). Keluarga sebagai tempat pertama anak mempelajari segala hal dalam kehidupan. Dengan dukungan keluarga, maka rasa percaya diri dan motivasi untuk menghadapi kehidupan lebih optimis. Dukungan keluarga menurut Caplan (dalam Friedman, 1998) ; Sarafino, (2006) meliputi dukungan informasional, dukungan penilaian/penghargaan, dukungan emosional dan dukungan instrumental. Dukungan keluarga dapat berupa dukungan sosial keluarga internal seperti dukungan dari ayah, ibu, saudara kandung atau suami, isteri. Dukungan keluarga juga berupa dukungan sosial keluarga eksternal (Friedman, 1998)

Disamping dukungan keluarga, peran keharmonisan perkawinan orang tua juga tidak kalah pentingnya dalam pendidikan spiritual anak. Orang tua sebagai figur otoritas bagi anak dapat menjadi teladan dalam bersikap dan berperilaku. Orang tua yang harmonis dalam 
perkawinannya dapat mendukung dan menghantarkan anak-anaknya menuju kehidupan lebih layak, lebih bahagia dan lebih tenteram melalui pendidikan spiritual. Putranto (2012) mengemukakan bahwa kecerdasan spiritual berhubungan dengan keharmonisan keluarga sakinah. Demikian pula Rofiah (2013) mengemukakan bahwa keharmonisan keluarga berpengaruh terhadap kecerdasan spiritual anak. Jadi dapat disimpulkan bahwa peranan orang tua dalam pendidikan spiritual dapat menentukan pembentukan kecerdasan spiritual anak. Berdasar dari latar belakang inilah, peneliti tertarik untuk mengetahui peran dukungan keluarga dan keharmonisan perkawinan orang tua terhadap pendidikan spiritual anak.

\section{Metode Penelitian}

Metode pendekatan yang digunakan dalam penelitian ini adalah pendekatan kuantitatif. Azwar (2013) mengungkapkan bahwa pendekatan kuantitatif menekankan analisisnya pada data-data numerikal yang diolah dengan metode statistika. Selain itu, penelitian kuantitatif banyak dituntut menggunakan angka, mulai dari pengumpulan data, penafsiran terhadap data tersebut, serta penampilan hasilnya. Variabel dalam penelitian ini adalah dukungan keluarga sebagai variabel bebas, keharmonisan perkawinan orang tua sebagai variabel sertaan dan pendidikan spiritual anak sebagai variabel tergantung.

Teknik sampling dalam penelitian ini menggunakan teknik probabilty sampling dimana menurut Sugiyono (2014) probabilty sampling adalah teknik pengambilan sampel yang tidak memberikan peluang yang sama bagi setiap anggota populasi yang dipilih menjadi anggota sampel. Teknik tersebut yang dipakai dalam penelitian ini adalah quota sampling, dengan 30 orang sampel. Pengumpulan data dalam penelitian ini dengan menggunakan skala likert. Skala likert digunakan untuk mengukur sikap, pendapat, pro-kontra, positif-negatif terhadap suatu objek sosial (Azwar, 2013). Pengumpulan data dengan menggunakan tiga skala yaitu skala dukungan keluarga, skala keharmonisan perkawinan orang tua dan skala pendidikan spiritual anak. Teknik analisis data mengunakan analisis regresi berganda.

\section{Hasil Penelitian}

Menurut Sarjono (2011) analisis regresi adalah suatu analisis yang digunakan untuk mengukur pengaruh variabel bebas terhadap variabel terikat. Berikut hasil dari korelasi antar variabel. 
Tabel. 1. Hasil uji korelasi antar variabel

Correlations

\begin{tabular}{|ll|r|r|r|}
\hline & & $\begin{array}{c}\text { pendidikan } \\
\text { spiritual }\end{array}$ & $\begin{array}{c}\text { dukungan } \\
\text { keluarga }\end{array}$ & $\begin{array}{c}\text { keharmonisan } \\
\text { perkawinan }\end{array}$ \\
\hline Pearson Correlation & pendidikan spiritual & 1,000 &, 602 &, 580 \\
& dukungan keluarga &, 602 & 1,000 &, 672 \\
& keharmonisan perkawinan &, 580 &, 672 & 1,000 \\
\hline Sig. (1-tailed) & pendidikan spiritual &, 000 &, 000 &, 000 \\
& dukungan keluarga &, 000 &, 000 &, 000 \\
& keharmonisan perkawinan & 30 & 30 & 30 \\
\hline $\mathrm{N}$ & pendidikan spiritual & 30 & 30 & 30 \\
& dukungan keluarga & 30 & 30 & 30 \\
\hline
\end{tabular}

Berdasarkan hasil uji korelasi antar variabel pada tabel 1. tersebut diatas, diketahui bahwa terdapat hubungan positif antara dukungan keluarga dengan pendidikan spiritual anak yang ditunjukkan dengan koefisien korelasi sebesar 0,602. Demikian pula keharmonisan perkawinan orang tua menunjukkan ada hubungan positif dengan pendidikan spiritual anak sebesar 0,580. Sedangkan hubungan antara dukungan keluarga dan keharmonisan perkawinan memiliki hubungan positif sebesar 0,672 .

Tabel 2. Uji Anova

\begin{tabular}{|ll|r|r|r|r|r|}
\hline Model & & Sum of Squares & df & Mean Square & \multicolumn{1}{c|}{ F } & \multicolumn{1}{c|}{ Sig. } \\
\hline 1 & Regression & 745,016 & 2 & 372,508 & 9,696 & \multirow{2}{*}{$001^{\mathrm{b}}$} \\
& Residual & 1037,350 & 27 & 38,420 & & \\
& Total & 1782,367 & 29 & & & \\
\hline
\end{tabular}

a. Dependent Variable: pendidikan spiritual

b. Predictors: (Constant), keharmonisan perkawinan, dukungan keluarga

Berdasarkan tabel 2 tersebut diatas, diketahui $\mathrm{F}$ hitung sebesar 9,696 dengan signifikansi 0,001 $(<0,05)$ yang berarti signifikan. Maka dapat disimpulkan bahwa dukungan keluarga dan keharmonisan perkawinan memiliki pengaruh signifikan terhadap pendidikan spiritual anak.

Tabel 3. Besar kontribusi antar variabel Model Summary

\begin{tabular}{|l|r|r|r|c|}
\hline Model & R & R Square & $\begin{array}{c}\text { Adjusted R } \\
\text { Square }\end{array}$ & $\begin{array}{c}\text { Std. Error of the } \\
\text { Estimate }\end{array}$ \\
\hline 1 &, $647^{\mathrm{a}}$ &, 418 &, 375 & 6,198 \\
\hline
\end{tabular}

a. Predictors: (Constant), keharmonisan perkawinan, dukungan keluarga

b. Dependent Variable: Pendidikan spiritual anak

Berdasarkan tabel 3. model summary diperoleh besarnya hubungan antara peran dukungan keluarga dan keharmonisan perkawinan orang tua secara simultan terhadap pendidikan spiritual anak adalah sebesar 0,647 yang menunjukkan terjadi pengaruh yang cukup kuat. Adapun kontribusi secara simultan peran dukungan keluarga dan keharmonisan 
perkawinan orang tua terhadap pendidikan spiritual anak dapat dilihat dari nilai $\mathrm{R}$ Square sebesar 41,8 \%, sedangkan 58,2 \% dipengaruhi variabel lain. Kemudian untuk membuktikannya dengan uji signifikan secara keseluruhan.

Tabel 4. Uji regresi berganda

Coefficients $^{\mathrm{a}}$

\begin{tabular}{|ll|r|r|r|r|r|}
\hline & & \multicolumn{2}{|c|}{$\begin{array}{c}\text { Unstandardized } \\
\text { Coefficients }\end{array}$} & $\begin{array}{l}\text { Standardized } \\
\text { Coefficients }\end{array}$ & $\mathrm{t}$ & Sig. \\
\cline { 3 - 7 } & & \multicolumn{1}{c|}{ B } & Std. Error & Beta & & \\
\hline 1 & (Constant) & 67,659 & 19,249 & & 3,515 &, 002 \\
& dukungan keluarga &, 346 &, 177 &, 387 & 1,950 &, 042 \\
& keharmonisan perkawinan &, 219 &, 136 &, 320 & 1,612 &, 038 \\
\hline
\end{tabular}

a. Dependent Variable: pendidikan spiritual

Model persamaan regresi berganda untuk memperkirakan pendidikan spiritual anak (Y) yang dipengaruhi peran dukungan keluarga (X1) dan keharmonisan perkawinan (X2) adalah Y $=67,659+0,346 X_{1}+0,219 X_{2}$. Jika peran dukungan keluarga dan keharmonisan perkawinan orang tua $\left(X_{1}\right.$ dan $\left.X_{2}=0\right)$, maka diperkirakan pendidikan spiritual anak sebesar 67,659. Sedangkan jika peran dukungan keluarga dan keharmonisan perkawinan orang tua bertambah 1 poin $\left(X_{1}\right.$ dan $\left.X_{2}=5\right)$, maka pendidikan spiritual anak akan naik menjadi $Y=67,659+0,346$ (5) $+0,219(5)=70,484$. Koefisien regresi sebesar 0,346 dan 0,219 menunjukkan besaran penambahan pendidikan spiritual anak untuk setiap penambahan poin peran dukungan keluarga dan keharmonisan perkawinan orang tua.

\section{Diskusi}

Berdasarkan hasil uji statistik, diperoleh $\mathrm{F}$ hitung sebesar 9,696 dengan signifikansi $0,001(<0,05)$ yang berarti signifikan. Artinya hipotesis yang diajukan diterima, maka dapat disimpulkan bahwa peran dukungan keluarga dan keharmonisan perkawinan orang tua memiliki pengaruh signifikan terhadap pendidikan spiritual anak. Adapun kontribusi secara simultan peran dukungan keluarga dan keharmonisan perkawinan orang tua terhadap pendidikan spiritual anak dapat dilihat dari nilai R Square sebesar 41,8 \%, sedangkan 58,2 \% dipengaruhi variabel lain.

Peran dukungan keluarga dan keharmonisan perkawinan orang tua terhadap pendidikan spiritual anak dapat dilihat dari koefisien regresi sebesar 0,346 dan 0,219 yang menyatakan bahwa setiap penambahan 1 dukungan keluarga, maka pendidikan spiritual anak bertambah sebesar 0,346. Setiap penambahan 1 keharmonisan perkawinan orang tua, maka pendidikan spiritual anak bertambah sebesar 0,219. Karena nilai koefisien bertambah positif, maka memiliki arah hubungan yang searah. Kenaikan pada variabel dukungan keluarga dan keharmonisan perkawinan orang tua mengakibatkan peningkatan pada pendidikan spiritual 
anak. Oleh karena itu, semakin besar dukungan keluarga dan semakin harmonis perkawinan orang tua, maka semakin baik pendidikan spiritual anak.

Sebagaimana menurut Taylor, Lilis dan Le Mone, 1997 dan Craven Hirnle, 1996 (dalam Hamid, 2000) dijelaskan bahwa faktor penting yang dapat mempengaruhi spiritualitas seseorang adalah 1). Pertimbangan tahap perkembangan, dimana manusia mempunyai persepsi tentang Tuhan dan bentuk sembahyang yang berbeda menurut usia, seks, agama dan kepribadian manusia, 2). Keluarga, peran orang tua sangat menentukan dalam perkembangan spiritual seseorang. Oleh karena keluarga merupakan lingkungan terdekat dan lingkungan pertama seseorang dalam mempersepsikan kehidupan di dunia, maka pandangan seseorang pada umumnya diwarnai oleh pengalaman mereka dalam berhubungan dengan orang tua dan saudaranya. 3). Latar belakang etnik dan budaya. Sikap, keyakinan dan nilai dipengaruhi oleh latar belakang etnik dan sosial budaya. Pada umumnya seseorang akan mengikuti tradisi agama dan spiritual keluarga. 4). Pengalaman hidup sebelumnya. Pengalaman hidup baik yang positif maupun pengalaman negatif dapat mempengaruhi spiritualitas seseorang. Sebaliknya juga dipengaruhi oleh bagaimana seseorang mengartikan secara spiritual kejadian atau pengalaman tersebut. 5). Krisis dan perubahan. Krisis dan perubahan dapat menguatkan kedalaman spiritual seseorang. Krisis sering dialami ketika seseorang menghadapi penyakit, penderitaan, proses penuaan, kehilangan dan bahkan kematian, khususnya pada pasien terminal atau dengan prognisis yang buruk. 6). Terpisah dari ikatan spiritual. Menderita sakit terutama yang bersifat akut seringkali membuat individu merasa terisolasi dan kehilangan kebebasan pribadi dan sistem dukungan sosial. 7). Isu moral terkait dengan terapi. Pada kebanyakan agama, proses penyembuhan dianggap sebagai caraTuhan untuk menunjukkan kebesarannya walaupun ada juga agama yang menolak intervensi pengobatan. 8). Asuhan keperawatan yang kurang sesuai.

Sari dan Jannah (2018) mengemukakan bahwa dukungan keluarga mempengaruhi pemenuhan kebutuhan spiritual. Dukungan keluarga adalah sikap, tindakan dan penerimaan keluarga terhadap anggotanya. Anggota keluarga memandang bahwa orang yang bersifat mendukung selalu siap memberikan pertolongan dan bantuan jika diperlukan (Friedman, 1998). Dukungan keluarga menurut Caplan (dalam Friedman, 1998) ; Sarafino (2006) meliputi dukungan informasional, dukungan penilaian/penghargaan, dukungan emosional dan dukungan instrumental. Dalam dukungan informasional, keluarga berfungsi sebagai sebuah kolektor dan diseminator (penyebar) informasi tentang dunia. Aspek-aspek dalam dukungan ini adalah nasehat, usulan, saran, petunjuk dan pemberian informasi. Dalam dukungan penilaian, keluarga bertindak sebagai sebuah bimbingan umpan balik, membimbing dan menengahi pemecahan masalah, sebagai sumber dan validator identitas anggota keluarga diantaranya memberikan support, penghargaan, perhatian. Dalam dukungan instrumental, keluarga merupakan sebuah 
sumber pertolongan praktis dan konkrit, diantaranya: kesehatan, kebutuhan makan, minum, istirahat, terhindar dari kelelahan. Sedangkan dalam dukungan emosional, keluarga sebagai tempat yang aman dan damai untuk istirahat dan pemulihan serta membantu penguasaan terhadap emosi. Aspek-aspek dari dukungan emosional meliputi dukungan yang diwujudkan dalam bentuk afeksi, adanya kepercayaan, perhatian, mendengarkan dan didengarkan.

Tidak hanya dukungan keluarga, yang tidak kalah pentingnya dalam pendidikan spiritual anak adalah keharmonisan perkawinan orang tua. Putranto (2012) mengemukakan bahwa kecerdasan spiritual berhubungan dengan keharmonisan keluarga sakinah. Demikian pula Rofiah (2013) mengemukakan bahwa keharmonisan keluarga berpengaruh terhadap kecerdasan spiritual anak. Pertanyaannya adalah mengapa keharmonisan perkawinan orang tua dapat mempengaruhi pendidikan spiritual anak. Perkawinan yang harmonis akan menciptakan kehidupan yang tenteram dan damai di dalam keluarga. Hal tersebut sangat memungkinkan anggota keluarga akan merasa nyaman untuk tinggal di dalamnya, saling mengasihi dan menyayangi. Soetjiningsih (1995) mengemukakan bahwa dalam kehidupan yang diwarnai oleh rasa kasih sayang, maka semua pihak dituntut agar memiliki tanggung jawab, pengorbanan, saling tolong menolong, kejujuran, saling mempercayai, saling membina, pengertian dan damai dalam rumah tangga. Di sisi lain setiap orang memiliki kebutuhan akan spiritualitas. anak sebagai anggota keluarga dalam tumbuh kembangnya membutuhkan pendidikan spiritual dari orang tuanya. Dengan kehidupan perkawinan yang harmonis, maka setiap orang tua berupaya untuk memenuhi kebutuhan anggota keluarga yang lain, yaitu anak-anak mereka, baik kebutuhan jasmani maupun rohani, kebutuhan fisik dan psikologis, sehingga dibutuhkan pendidikan spiritual anak. Dengan rasa kasih sayang dan tanggung jawab orang tua menjalankan perannya memenuhi kebutuhan-kebutuhan tersebut, termasuk didalamnya kebutuhan spiritual anak. Peranan orang tua dalam pendidikan spiritual dapat menentukan pembentukan kecerdasan spiritual anak.

Allah berfirman :

1. Sesungguhnya beruntunglah orang-orang yang beriman, 2. (yaitu) orang-orang yang khusyu' dalam sembahyangnya, 3. dan orang-orang yang menjauhkan diri dari (perbuatan dan perkataan) yang tiada berguna, 4. dan orang-orang yang menunaikan zakat, 5. dan orang-orang yang menjaga kemaluannya, 6. kecuali terhadap isteri-isteri mereka atau budak yang mereka miliki[994]; Maka Sesungguhnya mereka dalam hal ini tiada terceIa. 7. Barangsiapa mencari yang di balik itu[995] Maka mereka Itulah orang-orang yang melampaui batas. 8. dan orang-orang yang memelihara amanat-amanat (yang dipikulnya) dan janjinya. 9. dan orang-orang yang memelihara sembahyangnya. 10. mereka Itulah orang-orang yang akan mewarisi, 11. (yakni) yang akan mewarisi syurga Firdaus. mereka kekal di dalamnya. (Al-Mu'minun : 1-11)

Dengan hal tersebut maka pendidikan spiritual benar-benar telah menjadi salah satu pilar pembentuk pertumbuhan /perkembangan yang sempurna dan tanpanya tak akan lengkap pembentukan kepribadian manusia yang mana selalu berhadapan/ berlawanan dengan waktu 
yang merusak, kesusahan, yang diakibatkan oleh banyaknya gangguan dan rentannya terkena krisis (kegentingan/gangguan/ problema).

\section{Kesimpulan}

Peran dukungan keluarga dan keharmonisan perkawinan orang tua terhadap pendidikan spiritual anak menunjukkan arah yang positif dan signifikan. Artinya semakin besar dukungan keluarga dan semakin harmonis perkawinan orang tua, maka semakin baik pendidikan spiritual anak. Pendidikan spiritual menjadi salah satu pilar pembentuk pertumbuhan/ perkembangan yang sempurna dalam pembentukan kepribadian manusia. Oleh karena itu, dibutuhkan dukungan keluarga dan keharmonisan perkawinan orang tua dalam menjalankan perannya mengajarkan tata cara untuk melakukan hubungan personal dengan alam, dengan diri sendiri, dengan orang lain dan dengan Tuhan melalui sikap, tindakan maupun contoh perilaku yang baik pada anak.

\section{Daftar Pustaka}

Azwar, S. 2013. Reliabilitas Dan Validitas. Yogyakarta Pustaka Pelajar.

Friedman, M.Marilyn. 1998. Keperawatan Keluarga : Teori dan Praktik. Jakarta : EGC

Friedman, M. 2010. Buku Ajar Keperawatan keluarga : Riset, Teori, dan Praktek. Edisi ke-5. Jakarta: EGC

Hamid, Yani Achir. 2000. Buku Ajar Aspek Spiritual dalam Keperawatan. Jakarta: Widya Medika.

Herawati \& Edi . 2016. Aplikasi Komputer Untuk Psikologi. Malang : AE Publishing.

Putranto, Hendri Tri. 2012. Hubungan antara Kecerdasan Spiritual dengan Keharmonisan Keluarga Sakinah. Skripsi Univ.Muhammadiyah Surakarta. Diakses tgl 12 November 2018.

Rofiah, Alifatur (2013) Pengaruh keharmonisan keluarga terhadap tingkat kecerdasan spiritual anak di MI Miftahul Huda Kedunglumpang Jombang. Undergraduate thesis, Universitas Islam Negeri Maulana Malik Ibrahim. Diakses tanggal 12 November 2018.

Sarafino, E.P. 2006. Health Psychology: Biopsychosocial Interactions. Fifth Edition. USA: John Wiley \& Sons.

Sari, Intan Sukma \& Jannah, Syarifah Rauzatul. 2018. Family support to The Fulfillmnt of Spiritual Requirements on Clients with Mental Illness. www.jim.unsyiah.ac.id/FKep/ article/ download/4314/3014. Diakses tgl 12 November 2018. 
Sarjono, Haryadi. (2011). Spss vs Lisrel: Sebuah Pengantar, Aplikasi Untuk Riset. Jakarta: Penerbit Salemba Empat

Sugiyono. 2014 . Metode Kuantitatif Kualitatif, $R \& D$. Bandung: Alfabeta.

Saifudin, Lukman Hakim. 2018. https://www.era.id/read/1YUMBL-fakta-di-balik-tingginyaangka-perceraian-di-indonesia. Diakses tanggal 14 November 2018 